\title{
Метилотрофия у Azospirillum thiophilum BV-S
}

\author{
Руденко Т.С., Орлова М.В., Слепченко А.В., Шацкий Н.Д., \\ Смольяков Д.Д., Грабович М.Ю.
}

ФГБОУ ВО «Воронежский государственный университет», Воронеж

Поступила в редакцию 24.04.2018 г.

DOI: https://doi.org/10.17308/sorpchrom.2018.18/549

Целью данной работы было доказать способность Azospirillum thiophilum BV-S ${ }^{\mathrm{T}}$ к метилотрофному росту. Для этого были использованы следующие методы: культивирование бактерий в гетеротрофных и метилотрофных условиях, аннотирование генома с использованием автоматического аннотатора RAST, спектрофотометрическое измерение ферментативной активности, экстракция РНК с использованием сорбирующих микроколонок, обратная транскрипция, qPCR. B геноме Azospirillum thiophilum BV-S ${ }^{\mathrm{T}}$ выявлены гены, кодирующие ферменты окисления метанола, тетрагидрометаноптеринового пути, окисления формиата. Получены экспериментальные данные, подтверждающие наличие у Azospirillum thiophilum BV-S ${ }^{\mathrm{T}}$ способности к метилотрофному росту: показана высокая активность метанолдегидрогеназы и формиатдегидрогеназы в метилотрофных условиях; показано увеличение экспрессии генов $m d h 2$ и $x o x F$ при метилотрофном культивировании по сравнению с гетеротрофным.

Ключевые слова: Azospirillum thiophilum BV-S ${ }^{\mathrm{T}}$, метилотрофия, метанолдегидрогеназа, $m x a F, m d h 2, x o x F$.

\section{Methylotrophy in Azospirillum thiophilum BV-S}

\author{
Rudenko T.S., Orlova M.V., Slepchenko A.V., Shatskiy N.D., \\ Smoliakov D.D., Grabovich M.Y.
}

Voronezh State University, Voronezh

\begin{abstract}
Metanotrophs and methylotrophs are an ecologically significant group of microorganisms that are able to use reduced single-carbon compounds such as methane, methanol, methylated amines and methylated sulfur compounds as the single carbon source and as the energy source. These groups of microorganisms have a global significance as the main consumers of greenhouse gases and as key members of microbial communities living in environments full of organic C1-compounds. The genes encoding enzymes of methanol oxidation have also been found in the genomes of four other sequenced Azospirillum species, A. lipoferum, A. brasilense, A.oryzae and A. humicireducens. However there is still no experimental data establishing their ability to oxidize methanol at the moment.

The ability to oxidize single carbon compounds can be explained by the living conditions of this strain. A. thiophillum, unlike other representatives of the genus, that are localized in the soil, lives in hydrogen sulfide springs in oil and gas bearing area. Their metabolism leads to the production of methanol, formate and formaldehyde, that are oxidized by methylotrophic bacteria.

The aim of this work was to prove the ability of Azospirillum thiophilum BV-S to the methylotrophic growth. For this purpose the following methods were used: the cultivation of the bacteria in heterotrophic and methylotrophic conditions, annotation of the genome using the automatic annotator RAST, spectrophotometric measurement of the enzymatic activities, extraction of RNA using sorbent microcolumns, reverse transcription, qPCR. The genes encoding enzymes for methanol oxidation, tetrahydrometanopterine pathway and formate oxidation were identified in the genome of Azospirillum thiophilum BV-S. Experimental data
\end{abstract}


confirmed the ability of Azospirillum thiophilum BV-S to methylotrophic growth: high activity of methanol dehydrogenase and formate dehydrogenase in methylotrophic conditions; an increase in the expression of $m d h 2$ and $x o x F$ genes in methylotrophic cultivation as compared to heterotrophic was shown.

Keywords: Azospirillum thiophilum BV-S ${ }^{\mathrm{T}}$, methylotrophy, methanol dehydrogenase, $m x a F, m d h 2$, xoxF.

\section{Введение}

Прокариоты играют исключительно важную роль в процессах круговорота всех биогенных элементов. Особым экологически значимым типом метаболизма в биогеохимическом цикле углерода является метилотрофия - способность к использованию одноуглеродных соединений $\left(\mathrm{C}_{1}\right)$, таких как метанол, метилированные амины и метилированные соединения серы, в качестве единственного источника углерода и окисляемого источника энергии. Метилотрофы имеют глобальное значение как основные поглотители парниковых газов и ключевые элементы микробных сообществ зон холодного просачивания сульфидов, грязевых вулканов и других сред, богатых $\mathrm{C}_{1}$-соединениями.

Azospirillum thiophilum обитает в нефтегазовой области Ставропольского края. Эта область характеризуется выходом на поверхность метана и метановых вод. Таким образом, метаноокисляющие организмы скорее всего, присутствуют там, и их метаболизм приводит к образованию метанола, формиата и формальдегида. Гены, кодирующие ферменты окисления метанола, также были обнаружены в геномах двух других секвенированных видов Azospirillum - A.lipoferum и A. humicireducens, но до сих пор нет экспериментальных данных, устанавливающих их способность к окислению метанола на данный момент.

Целью данной работы являлось доказать способность Azospirillum thiophilum $\mathrm{BV}-\mathrm{S}^{\mathrm{T}}$ к метилотрофному росту в присутствии метанола, формиата.

\section{Эксперимент}

Объектом исследования служил штамм диазотрофных бактерий рода Azospirillum - Azospirillum thiophilum BV-S ${ }^{\mathrm{T}}$. Культивирование бактерий проводили с использованием жидкой PSS среды следующего состава, г/дм ${ }^{3}:\left(\mathrm{NH}_{4}\right)_{2} \mathrm{SO}_{4}-1.0$; $\mathrm{CaCl}_{2} \cdot 2 \mathrm{H}_{2} \mathrm{O}-0.03 ; \mathrm{MgSO}_{4} \cdot 7 \mathrm{H}_{2} \mathrm{O}-1.0$; сукцинат натрия - 1.0 ; пептон - 2.0; дистиллированная вода -1 дм $^{3}$, набор витаминов и микроэлементов [1]. Метилотрофный рост осуществляли с использованием среды вышеуказанного состава без сукцината натрия и пептона, добавляя в качестве источника электронов метанол или формиат $\left(0.5 \Gamma /\right.$ дм $\left.^{3}\right)$, в качестве источника углерода - $\mathrm{NaHCO}_{3}\left(0.5 \Gamma / \mathrm{дm}^{3}\right)$, лантаноиды $\left(0.03 \Gamma /\right.$ дм $\left.^{3}\right)$, дрожжевой экстракт $\left(0.1 \Gamma /\right.$ дм $\left.^{3}\right)[2,3]$.

Выделение РНК. РНК экстрагировали при помощи набора для выделения РНК из культур клеток (BioSilica, Россия) с сорбирующими микроколонками. Для этого клетки из культуральной среды (pH 7.0) осаждали центрифугированием, ресуспендировали в 250 мкл лизис-буфера и инкубировали на льду 15 мин. Затем центрифугировали 15 мин при 13000 об/мин и отбирали супернатант. К супернатанту добавляли равный объем буфера 1, перемешивали. На колонку наносили 200 мкл буфера 2, центрифугировали 1 мин при 13000 об/мин и удаляли фильтрат. Далее на носили на колонку подготовленный образец, центрифугировали 1 мин при 13000 об/мин и удаляли фильтрат. Наносили на фильтр 300 мкл буфера 2, центрифугировали 1 мин при 13000 об/мин и удаляли фильтрат. Дважды наносили на фильтр 500 мкл раствора для промывки 2, центрифугировали 1 мин при 13000 об/мин и удаляли фильтрат. Затем выливали содержимое пробирки и центрифугировали 1 мин при 
13000 об/мин и удаляли фильтрат. Переносили колонку в новую $1.5 \mathrm{~cm}^{3}$ пробирку, наносили на фильтр 150 мкл дистиллярованной воды и инкубировали микроколонку 1-3 мин при комнатной температуре. Затем центрифугировали 1 мин при 13000 об/мин. Полученный раствор содержал очищенную РНК (рН 7.0) [4].

Качество РНК оценивали с помощью электрофореза в 2\% агарозном геле [5]. Концентрацию РНК измеряли с Qubit R RNA HS Assay Kit (Thermo Fisher Scientific, USA) на флюориметре Qubit 2.0 (Thermo Fisher Scientific,USA). 1000 нг РНК затем были обратно транскрибированы с использованием M-MulV (SybEnzyme, Russia) и Eppendorf Mastercycler Personal согласно протоколу производителя. Количественную RT-PCR проводили с использованием SYBR Green I на Bio-Rad CFX96TM Real-Time System (Bio-Rad, USA) согласно следующему протоколу. Общую денатурацию проводили при $95^{\circ} \mathrm{C} 3$ мин; денатурация в начале цикла $95^{\circ} \mathrm{C} 20 \mathrm{c}$; отжиг праймеров $59^{\circ} \mathrm{C} 20$ с, элонгация $72^{\circ} \mathrm{C} 30$ c; кол-во циклов 39. В работе использовались следующие праймеры, подобранные в PrimerBLAST (http://www.ncbi.nlm.nih.gov/ tools/primer-blast/): Azo_mxaF_F2 (5'-GACCATGACCATTTTCGCCC3'), Azo_mxaF_R2 (5'-TATAGACGATTGCCGTTGCGG-3'), azo_mdh2_F (5'AAGGGGCTTCTACCAGCACAC-3'), azo mdh2_R GCTGTAGGACATCGGGTTCC-3'), Azo_xoxF_F (5'-GCCGTCATAGTCCCATTCGT3'), Azo_xoxF_R (5'-ATCAACACCGGCĀAGATGGT-3'). Первичное аннотирование генома проводили при помощи интернет-платформы RAST с использованием технологии подсистем (http://rast.nmpdr.org/).

Анализ ферментативной активности. Активность формиатдегидрогеназы [6], были измерены в супернатанте при $\lambda=340$ нм по скорости окисления коферментов НАДН или НАДФН, в соответствующей реакционной смеси. Активность метанолдегидрогеназы определяли по модифицированному методу Anthony C. и Zatman J. [7, 8]. Удельную активность ферментов выражали в мкмоль мин $^{-1} \cdot{ }^{-} \Gamma^{\circ}$ белка ${ }^{-1}$.

\section{Обсуждение результатов}

У метилотрофных бактерий окисление метанола до $\mathrm{CO}_{2}$ осуществляется в три последовательных этапа: метанол $\rightarrow$ формальдегид $\rightarrow$ формиат $\rightarrow \mathrm{CO}_{2}$.

В геноме A. thiophilum обнаружены три типа метанолдегидрогеназ, участвующих в превращении метанола до формальдегида: классическая метанолдегидрогеназа первого типа - mxaF (77.6\% идентичности с гомологичным белком Methylobacterium extorquens), метанолдегидрогеназа второго типа - mdh2, метанолдегидрогеназа третьего типа - $x o x F$ (идентичность $64.3 \%$ с гомологичным белком M.extorquens). Гены mxaI, mxaA, mxaC, mxaD, mxaK, mxaL, mxaJ, mxaG, mxaS, mxaR, $m x a B$, кодирующие ферменты mxa-кластера классической метанолдегидрогеназы, расположены на хромосоме 2 (рис. 1).

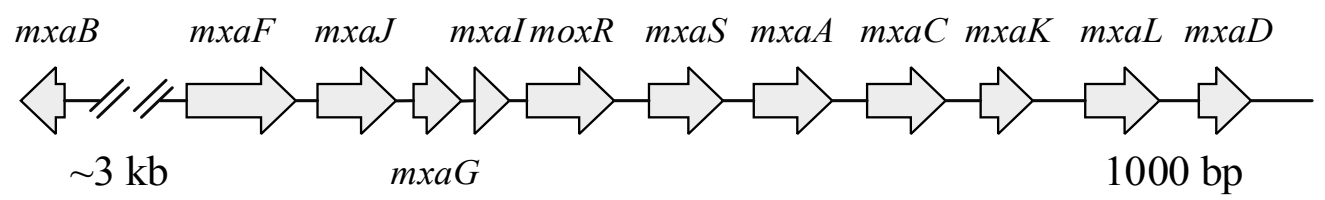

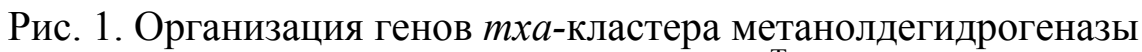
y Azospirillum thiophilum $\mathrm{BV}-\mathrm{S}^{\mathrm{T}}$.

Превращение формальдегида до формиата у A. thiophilum осуществляется при участии ферментов тетрагидрометаноптеринового пути. Формилметанофурандегидрогеназы C, A, B и N-формилтрансферазы (D) представлены комплексом формилметанофурантрансфераза/гидролаза (FTR/гидролазный комплекс), кодируемый генами 
fhc CDAB (Methylobacterium extorquens - CAX24163.1-CAX24166.1). Гены расположены на хромосоме 5 (рис. 2).

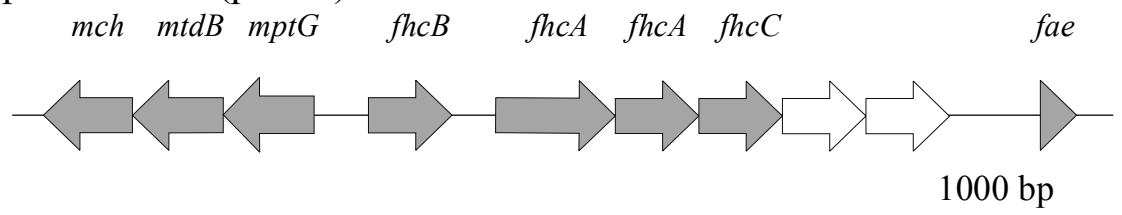

Рис. 2. Организация генов, кодирующих ферменты тетрагидрометаноптеринового пути у Azospirillum thiophilum BV-S.

Формиатдегидрогеназа, участвующая в дальнейшем окислении формиата до $\mathrm{CO}_{2}$ у A. thiophilum, представляет собой NAD-молибденсодержащую формиатдегидрогеназу, кодируемую генами $f d s A B G D$, и дополнительно три копии субъединицы альфа $(f d h A)$ и дельта $(f d h D)$.

Активность метанолдегидрогеназы (суммарная активность Мха и ХохF подтипов) составила 17.5 Е/мг белка. Установлено также, что активность метанолдегидрогеназы увеличивается в 3 раза (54 Е/мг белка) при культивировании в присутствии

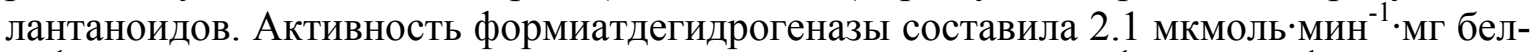
$\mathrm{\kappa a}^{-1}$, а при росте в присутствии лантаноидов -4.4 мкмоль $\cdot$ мин $^{-1} \cdot$ мг белка $^{-1}$.

Для дополнительного подтверждения способности A. thiophilum к метилотрофному росту изучена экспрессия генов $m d h 2$ и $x o x F$ при гетеротрофном и метилотрофном культивировании бактерий в присутствии метанола в качестве единственного источника энергии. Было показано увеличение экспрессии генов метанолдегидрогеназ $m d h 2$ и $x o x F$ в 3 и 1.6 раз, соответственно, при метилотрофном росте по сравнению с гетеротрофным.

Недавно взгляды на метилотрофию и даже биологическую роль металлов претерпели серьезные изменения в связи с открытием новой обширной группы высокоактивных метанолдегидрогеназ (МДГ) ХохF-типа, требующих для каталитической активности присутствия лантаноидов [9-11]. В связи с этим был выявлен уровень экспрессии гена $x o x F$ при метилотрофном культивировании бактерий с добавлением в питательную среду La (III).

Экспрессия гена $x o x F$ при метилотрофном культивировании с La (III) превысила экспрессию при гетеротрофном и метилотрофном культивировании без La (III) в 22.7 и 14 раз, соответственно.

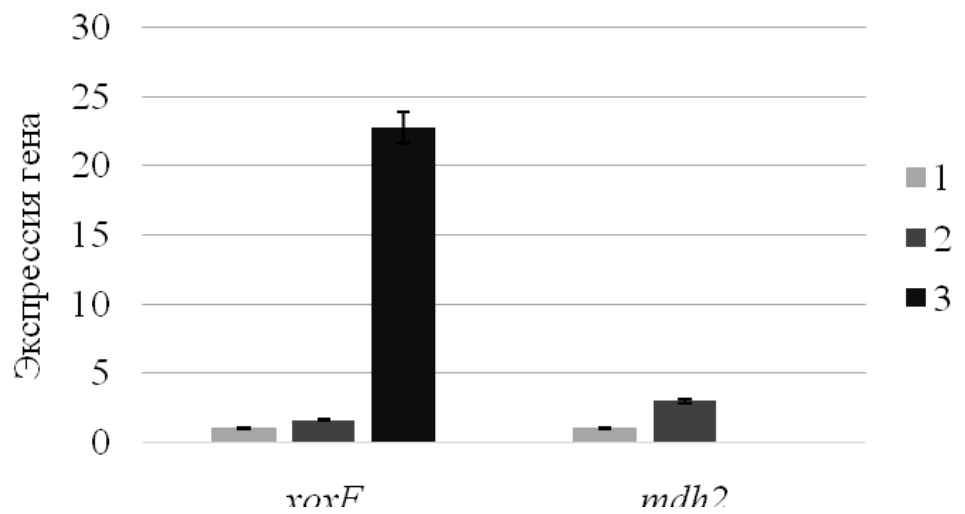

Рис. 3. Уровень экспрессии генов mdh2 и хохF у Azospirillum thiophilum BV-S в гетеротрофных и метилотрофных условиях культивирования.

1 - гетеротрофные условия роста, 2 - метилотрофные условия роста, 3 - метилотрофные условия роста с La (III). 


\section{Заключение}

Было доказано наличие у Azospirillum thiophilum BV-S ${ }^{\mathrm{T}}$ способности к метилотрофному росту, что подтверждается увеличением экспрессии генов $m d h 2$ и $x o x F$ при метилотрофном культивировании по сравнению с гетеротрофным, наличием всех генов, кодирующих ферменты окисления метанола, тетрагидрометаноптеринового пути, окисления формиата, а также высокая активность метанолдегидрогеназы и формиатдегидрогеназы в метилотрофных условиях по сравнению с гетеротрофными.

\section{Список литературы}

1. Pfenning N.D., Lippert K.D. // Arch. Microbiol. 1966. Vol. 55. pp. 245-256.

2. Hartner F. S., Glieder A. // Microb Cell Fact. 2006. Vol. 5. pp. 39.

3. Palmer M. // Microbial Cell Factories. 2017. Vol.16. pp.49-79.

4. Селеменев В.Ф., Славинская Г.В., Хохлов В.Ю., Чикин Г.А. Практикум по ионному обмену. Воронеж. 1999. 160 с.

5. Hartmann T., Leimkuhler S. // FEBS J. 2013. Vol. 280. pp. 6083-6096.

6. Селеменев В.Ф., Рудаков О.Е., Славинская Г.В., Дроздова Н.В. Пигменты пище-

\section{References}

1. Pfenning N.D., Lippert K.D., Arch. Microbiol., 1966, Vol. 55, pp. 245-256.

2. Hartner F. S., Glieder A., Microb Cell Fact, 2006, Vol. 5, pp. 39.

3. Palmer M., Microbial Cell Factories, 2017, Vol.16, pp.49-79.

4. Selemenev V.F., Slavinskaja G.V., Hohlov V.Ju., Chikin G.A., Praktikum po ionnomu obmenu, Voronezh, 1999, $160 \mathrm{p}$.

5. Hartmann T., Leimkuhler S., FEBS J., 2013, Vol. 280, pp. 6083-6096.

6. Selemenev V.F., Rudakov O.E., Slavinskaja G.V., Drozdova N.V., Pigmenty pishhevyh

Руденко Татьяна Сергеевна - студент Воронежского госуниверситета, Воронеж

Орлова Мария Валерьевна - аспирант Воронежского госуниверситета, Воронеж

Слепченко Ангелина Викторовна - студент Воронежского госуниверситета, Воронеж

Шацкий Николай Дмитриевич - студент Воронежского госуниверситета, Воронеж

Смольяков Дмитрий Денисович - студент Воронежского госуниверситета, Воронеж

Грабович Маргарита Юрьевна - д.б.н., профессор кафедры биохимии и физиологии клетки Воронежского госуниверситета, Воронеж вых производств (меланоидины). М. ДеЛи принт. 2008. 246 c.

7. Anthony C., Zatman L. J. // Biochem J. 1967. Vol. 104. pp. 960-969.

8. Kalyuzhnaya M.G, Lapidus A, Ivanova N. et al. // Nat Biotechnol. 2008. Vol. 26. pp. 102934.

9. Masuda S., Suzuki Y., Fujitani Y. et al. // mSphere. 2018. Vol. 3. pp. 462-17.

10.Skovran E., Palmer A.D., Rountree A.M. et al. // J Bacteriol. 2011. Vol. 193. pp. 6032-8.

11.Vu H.N, Subuyuj G.A, Vijayakumar S. et al. // J Bacteriol. 2016. Vol. 198. pp. 12501259 .

proizvodstv (melanoidiny), M., DeLi print, 2008, $246 \mathrm{p}$.

7. Anthony C., Zatman L.J., Biochem J., 1967, Vol. 104, pp. 960-969.

8. Kalyuzhnaya M.G, Lapidus A, Ivanova N. et al., Nat Biotechnol., 2008, Vol. 26, pp. 102934.

9. Masuda S., Suzuki Y., Fujitani Y. et al., mSphere, 2018, Vol. 3, pp. 462-17.

10.Skovran E., Palmer A.D., Rountree A.M. et al., J Bacteriol., 2011, Vol. 193, pp. 6032-8.

11. Vu H.N, Subuyuj G.A, Vijayakumar S. et al., J Bacteriol., 2016, Vol. 198, pp. 1250-1259.

Rudenko Tatiana S. - student in Voronezh State University, Voronezh, e-mail: tsrudenko95@gmail.com

Orlova Maria V. - PhD student in Voronezh State University, Voronezh

Slepchenko Angelina V.- student in Voronezh State University, Voronezh

Shatskiy Nikolay D. - student in Voronezh State University, Voronezh

Smoliakov Dmitriy D. - student in Voronezh State University, Voronezh

Grabovich Margarita Yu. - professor in the Department of Cell Biochemestry and Physiology, Voronezh State University, Voronezh 